\title{
Interest Groups, NGOs or Civil Society Organisations? The Framing of Non-State Actors in the EU
}

\author{
Jonas J. Schoenefeld ${ }^{1,2}$
}

Accepted: 3 October 2020/Published online: 26 October 2020

(C) The Author(s) 2020

\begin{abstract}
Scholars have used varying terminology for describing non-state entities seeking to influence public policy or work with the EU's institutions. This paper argues that the use of this terminology is not and should not be random, as different 'frames' come with different normative visions about the role(s) of these entities in EU democracy. A novel bibliometric analysis of 780 academic publications between 1992 and 2020 reveals that three frames stand out: The interest group frame, the NGO frame, as well as the civil society organisation frame; a number of publications also use multiple frames. This article reveals the specific democratic visions contained in these frames, including a pluralist view for interest groups; a governance view for NGOs as 'third sector' organisations, and participatory and deliberative democracy contributions for civil society organisations. The use of these frames has dynamically changed over time, with 'interest groups' on the rise. The results demonstrate the shifting focus of studies on non-state actors in the EU and consolidation within the sub-field; the original visions of European policy-makers emerging from the 2001 White Paper on governance may only partially come true.
\end{abstract}

Keywords Interest group - NGO - Civil society organisation $\cdot$ Lobbying $\cdot$ Framing $\cdot$ EU

Jonas J. Schoenefeld

j.schoenefeld@iwu.de

1 Institute of Political Science, Technical University of Darmstadt, Dolivostraße 15, 64293 Darmstadt, Germany

2 Tyndall Centre for Climate Change Research, School of Environmental Sciences, University of East Anglia, Norwich, UK

\section{Introduction}

Scholars and practitioners variously describe non-state actors such as Greenpeace as 'civil society organisations' (CSO), 'interest groups', 'non-governmental organisations' (NGO), 'not-for-profit organisations', or 'third sector organisations', to name but a few of the plethora of terms that has emerged over time (see Enjolras et al. 2018, Chapter 1). Those new to the field will likely find this state of affairs confusing; practitioners may either perceive such proliferation of terminology as useless academic squabbles or- to the extent that they have tuned into the finer lines of debate-may use the terms strategically. More than ten years ago, Beyers et al. (2008) drew attention to this problem by arguing that 'it is quite remarkable how such a relatively modest field is so heavily Balkanised'. They argued that different conceptual approaches have resulted from historical use of terminology, but crucially also point to linked normative assumptions, particularly in the case of 'civil society' (Beyers et al. 2008). In the intervening decade, limited progress has been made to advance these conceptual debates, let alone track them over time. This paper addresses this gap by asking what terms have been used to describe and analyse non-state actors over time, and what normative visions are attached to them insofar as they relate to the EU's evolving democracy. Doing so is relevant not only for research endeavours on the role of non-state actors in the EU, but also for practitioners seeking to work with non-state actors.

Analytically, this paper draws on the tool of a 'frame'. Frames are 'underlying structures or organizing principles that hold together and give coherence to a diverse array of symbols, idea elements, metaphors and other cognitive elements' (Creed et al. 2002, p. 36; see also Shore and Wright 1997). They are thus 'schemata of interpretation', 
or mental structures, which order what would otherwise appear disjointed (Goffman 1974, p. 21; see also Creed et al. 2002). Framing implies organising cognitive elements such as ideas, practices, or beliefs into coherent networks (Benford and Snow 2000). Analysing frames has gained popularity in social sciences as a way of expanding our understanding of how people make meaning in networked ways, including framing endeavours by non-state actors (Boräng et al. 2014). This paper in turn argues that terminological choices in describing non-state actors matter, because each term signifies underlying ideational networks or frames about the roles and functions of these organisations in democratic systems (see Kutay 2017). While the paper adopts 'non-state actor' for narrative purposes-in line with the Oxford Dictionary of English (3rd ed.) understanding a non-state actor broadly as 'an individual or organization that has significant political influence but is not allied to any particular country or state', it seeks to disentangle the terminology used in scholarship in order to shine a spotlight on academia's key role in framing nonstate actors. While non-state actors may include armed or terrorist groups (see Clapham 2009, p. 200), the focus of this paper is on actors that are generally considered legitimate elements of EU governance.

Developing a better understanding of the framing of non-state actors by researchers matters for two reasons: first, it contributes to the conceptual clarity of the field, which is undermined if terminology is used uncritically or randomly, and especially if underlying normative implications remain unclear (Beyers et al. 2008). Clear concepts are also a precondition for fruitful empirical explorations (see Baroni et al. 2014; Sartori 1970). Second, this paper argues that more than mere conceptual and definitional issues are at stake, because each frame captures a normative vision about the role of non-state actors in the delivery of social values and public goods such as democracy, environmental protection, citizen engagement, and others. Frames may influence other academics, policy-makers, and citizens regarding (1) what we can expect from non-state actors and (2) the normative role that non-state actors should play in the European polity. Scholars have already noted the power of framing that non-state actors conduct themselves (Boräng et al. 2014; Boräng and Naurin 2015; Klüver and Mahoney 2015). It is thus high time to consider how scholars frame non-state actors in their own work and with what (explicit or implicit) normative connotations.

Empirically, this paper contributes a fresh bibliometric analysis of a novel literature database containing 780 academic publications on non-state actors in the European Union (EU) that have appeared between 1992 and 2020. The EU has been identified as a particularly dynamic site of non-state actor interest and involvement-often described as various forms of lobbying. The growth of these activities has attracted the attention of an international community of scholars (Bunea and Baumgartner 2014). Prominent existing studies have addressed the number of EU non-state actors (Berkhout et al. 2015; Wonka et al. 2010), their funding and regulation (see Greenwood 2017), their access to the European institutions (e.g. Albareda and Braun 2019; Arras and Beyers 2020; Coen and Katsaitis 2019), their influence (Dür, 2007; Klüver 2013), their strategies as well as their professionalisation (Klüver and Saurugger 2013; Maloney et al. 2018). A second reason why the EU is a particularly useful site of empirical study for the current paper is that has always been an evolving political system with vibrant debates on its democratic nature and quality (e.g. Warleigh 2003), which has stimulated research on the role of non-state actors' contribution to democratic governance (Kohler-Koch and Quittkat 2013; Saurugger 2008).

The paper proceeds as follows: It starts with an overview of framing approaches and then describes the empirical methods, namely combining bibliometric and keyword analyses with a literature review in order to expose the prevalence and emergence of prevalent frames of non-state actor research in the EU. The fourth section disentangles prominent conceptual frames and demonstrates how they contain democratic ideals of the EU polity. The paper concludes by highlighting the growing importance of academic framing in EU non-state actor politics.

\section{Framing Approaches}

Framing approaches have been especially popular among social movement scholars, who ask how social movement leaders frame strategically to mobilise people (Snow et al. 1986). For instance, 'collective action frames' combine events and information that may otherwise seem disconnected, in order to define problems and, after linking them to solutions, provide rationales for action (Benford and Snow 2000; Rein and Schön 1991). In political terms, frames can be powerful-for example, 'old' issues can be turned into 'new' ones by reframing them (Chong and Druckman 2007) and one can bridge, connect, and extend, but also manipulate frames and use them strategically (Mazey and Richardson 1997). In Lakoff's (2004) terms,

In politics our frames shape our social policies and the institutions we form to carry out policies. To change our frames is to change all of this. Reframing is social change. (p. $\mathrm{XV}$; emphasis in original).

For example, Ruzza (2004, p. 58) explains how governments and non-state actors reframed 'environmentalism' as 'sustainable development' and how this new frame 
enabled business actors to collaborate on environmental issues. This paper argues that social scientists create and manipulate frames by describing and researching social or political phenomena, including non-state actors. Precisely because terms such as CSO or NGO remain diffuse and variable, their use implies constant re-framing and linking with normative ideas about the their (political) context (here the European polity), even if this happens in an academic environment.

Not all frames are equally effective. Benford and Snow (2000) identify a few 'master frames' that have been used to rally large constituencies behind certain causes, such as the 'environmental justice frame'. Some frames resonate more than others, depending on their fit with social movements, the wider life-world and whether people articulating them are perceived as credible (Benford and Snow 2000). Frame efficacy also depends on institutional environments (Ruzza 2004). Those studying framing should therefore identify whether certain master frames exist and consider their interactions with outside factors.

Finally, framing is a dynamic process because people intentionally or unintentionally change, adjust and sometimes manipulate frames (Chong and Druckman 2007; see also Benford and Snow 2000; Tarrow 1992). Callon (1998) argues that frames are inherently dynamic because the elements they comprise remain connected with the world by virtue of their origin. This creates constant frame 'overflow', meaning that frame contents contribute to ongoing frame emergence and re-framing (Callon 1998). In light of these properties, there is to date very limited knowledge on the origin of frames, how they move through political space, and how long they remain more or less stable (Chong and Druckman 2007; but see Entman 2009; Gamson 2005).

This paper focuses on the framing of non-state actors by academia in the EU, while fully recognising that other actors such as politicians and bureaucrats may also contribute to this process (see Smismans 2003). It also remains cognizant of frame dynamism, which includes horizontal interactions, levels of frame overlap, and frame differentiation. Importantly, framing processes are often highly political because their outcomes may have implications for access to reputational, monetary, and other resources. For example, certain CSOs receive financial support from the EU institutions (Bouwen 2009). The following section describes the methods used in order to identify prevalent frames and their dynamic emergence in research on nonstate actors over time.

\section{Methods}

This section describes the methods applied to create the new database and to analyse it with bibliometric tools.

\section{Assembling the New Database}

The first step involved searching the prevalent academic databases Scopus, ${ }^{\circledR}$ Web of Knowledge, ${ }^{\text {SM }}$ and Proquest International Bibliography of the Social Sciences (IBSS) for relevant academic publications. These databases provide a broad, multidisciplinary coverage of multiple academic fields including political science, sociology, and geography. The approach applied in this research is thus more comprehensive than earlier efforts, which had exclusively focused on political science and public policy studies (Bunea and Baumgartner 2014). The sample from these databases thus provides a good estimation of the nature of publications on non-state actors (Andrés 2009). The search was based on an extensive collection of terms or keywords ${ }^{1}$ drawn from the literature review by Beyers and colleagues (2008) and turned into search text with Boolean indicators. The raw data were imported into the reference management software program Citavi and duplicates removed. The search includes all journal articles, book chapters, and other relevant publications, while books on the subject were excluded. ${ }^{2}$ In addition, all articles whose titles and/or abstracts did not clearly indicate that they were about non-state actors in the EU were removed.

\section{Bibliometric Analysis}

The second step involved analysing the full database with bibliometric approaches (Andrés 2009; Donohue 1973) in order to evaluate the prevalence of frames in literatures on non-state actors in the EU. First, the publication year was recorded for each item in the qualitative analysis software NVIVO. Second, depending on the emergence of keywords in the titles and abstracts, publications were coded into corresponding categories signifying descriptive frames ${ }^{3}$; four frame signifiers emerged as strongest, namely interest group; NGO; civil society organisation; and multiple

\footnotetext{
1 The search for relevant documents used the following keywords (linguistic variations were included and in relevant cases captured with 'wild cards' and combinations defined with Boolean operators): European Union, interest group, political interest, political interest group, interest association, interest organisation, organised interest, pressure group, specific interest, special interest group, citizen group, public interest group, nongovernmental, nongovernmental organisation, social movement organisation, civil society organisation, third sector, lobby, lobbying, charity, and nonprofit.

${ }^{2}$ Books were excluded because they could not be retrieved and analysed in their entirety.

3 The analysis started with the existing frames retrieved from extant literatures, but also added more terms inductively throughout the process in order to enable the categorisation of the vast majority of publications. Nineteen publications (or $2.4 \%$ of the database) could not be categorised and were thus marked as 'unassigned'.
} 
frames. Keywords that did not feature in at least 10 articles in any one year between 1992 and $2020^{4}$ are not reported. ${ }^{5}$ Third, each publication was subjected to a keyword query using NVIVO. To this end, each publication was stripped of its bibliography and the software then identified the most commonly used keywords in all publications that had been assigned to one of the four main frame signifiers. Only words with three or more characters were included in the analysis, and word clouds were generated in order to support interpretation. In parallel, a literature review was conducted in order to identify linkages between the terms identified, drawing on the author's knowledge of the field, as well as on the contents of the database.

\section{Results}

\section{Bibliometric Analysis}

The initial combined database search returned more than 3000 hits (see Table 1). ${ }^{6}$ The search involved all publications that the author was able to retrieve from as early as possible (1992) until June 2020.

After the initial data screening (see above), including removing duplicates and sifting through the studies that resulted from this process, 780 publications remained. In total, the publications from the three major frames and those using multiple fames sum up to 669 publications or $85.9 \%$ of the database. The analysis demonstrates that nearly half of the publications fell into the 'interest group' frame, followed by 'NGOs', 'multiple frames', and 'civil society organisation'. See Fig. 1. Figure 2 reveals the remarkable general growth of publications on non-state actors, beginning in the early 2000s. Furthermore, this figure reveals the rise of 'civil society' as a keyword in article titles from the early 2000s onwards, remaining roughly on par with 'NGO'. The 'interest group' frame began dominating in the early 2000s; note that the numbers for 2020 only include the first half of the year.

A second step involved tracing the emergence of the four major frames in academic publications over time (see Fig. 2).

\footnotetext{
4 The time span used in this analysis was based on available data from the searches; 1992 was the earliest contribution recorded in this dataset.

5 These include: advocacy organisation, corporate lobbying, lobbying coalition, lobby organisation, non-profit organisation, non-state actors, organised interest, pressure group, social movement organisation, and voluntary organisation.

${ }^{6}$ This research began in 2013 and was updated and finalised in 2020.
}

\section{Prevalent Frames in Research on Non-state Actors in the $\mathbf{E U}$}

This section unpacks the contents of each main frame in greater detail, drawing on the keyword-based insights as well as on a corresponding literature review.

\section{The 'Interest Group' Frame}

The 'interest group' frame has by and large been the most popular in the study of non-state actors in the EU. But it is also a contentious concept in political science. As Jordan et al. (2004) explain, interest groups were originally constituted and sustained by individual members (see also Dalziel 2010). As such, they have an 'underlying rationale' that is based on the attitudes or interests of their members (Eising and Lehringer 2013). In practice, scholars often deviate from this membership-based idea by categorising all groups that seek to influence political processes as 'interest groups' (Jordan et al. 2004). As a response, some have sought to clarify the concept by refocusing it on the original membership-inspired idea while engaging with functional approaches: Jordan and colleagues (2004) suggest labelling all entities which seek to influence public policy as 'pressure participants', but distinguishing between 'policy participants', which would be individual companies, and interest/pressure groups, which are typically groups of individuals or other organisations/companies that seek to influence the policy process. However, some staff-based groups may also be classified as interest groups (Jordan et al. 2004).

Others, such as Beyers and colleagues (2008) seek to define an interest group based on the key organisational features of 'organisation', 'political interests', and 'informality'. The 'organisation' component distinguishes the interest groups from other influences on public policy, such as social movements or public opinion. 'Political interest' means that these groups seek to influence public policy, and 'informality' refers to the fact that these groups do not seek formal political positions (Beyers et al. 2008). Beyers and colleagues (2008) highlight that this fairly broad definition encompasses a diverse spectrum of actors.

The aforementioned attempts to clarify the concept are mostly done by researchers seeking to operationalise the concept for data collection. There are, however, normative notions included in the 'interest group' frame. The basic idea is that there are multiple groups in a polity pushing for the interests that they represent-and therefore the frame implies pluralist notions of democratic governance (Truman 1951). This idea assumes that interest groups have more or less fixed preferences which are brought to the fore and worked through the relevant institutional context, such as the EU (Mansbridge 1992). Policy-makers appear to 
Table 1 Identifying frames in research on non-state actors in the EU

\begin{tabular}{ll}
\hline Source & Number of publications \\
\hline SCOPUS & 1812 \\
Web of Knowledge & 886 \\
Proquest International Bibliography of the Social Sciences (IBSS) & 571 \\
Total & 3269 \\
Total after removing duplicates & 2508 \\
Final sample (relevant \& retrievable publications) & 780 \\
\hline
\end{tabular}

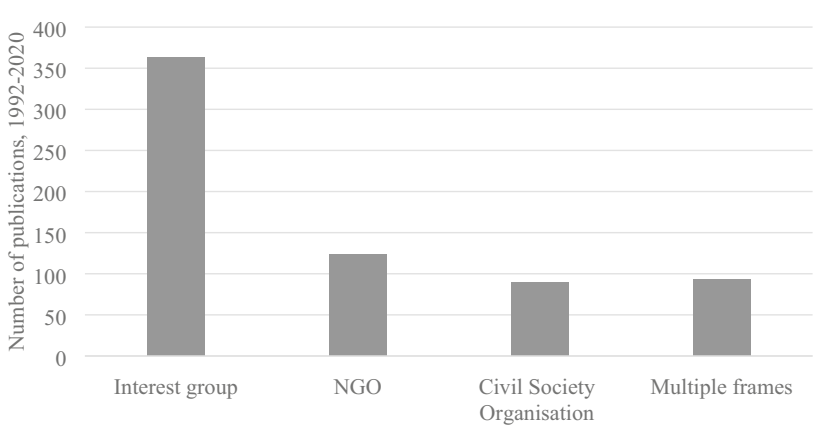

Fig. 1 Key frames in academic publications on non-state actors in the EU

have had different perceptions-Doliwa-Klepacka (2011) argues that the European Commission introduced the frame, because it felt that it was politically anodyne, especially compared to the term lobbyist/lobbying, which was thought to contain negative connotations. The fact that the keyword 'lobby' ranks in the top ten words used in publications with 'interest group' in the abstract/title shows that this is one of the key contents of the 'interest group' frame. However, the word 'member' also emerges in 12th place, indicating that some elements remain from its original formulation (see Fig. 3). In this line of thinking, the 'interest group' label insinuates a 'Europe of interests'. The latter argument sits well with liberal democratic ideas about political processes (Held 2006). These normative notions are easily forgotten when the term interest group is used.

\section{The 'Non-Governmental Organisation' (NGO) Frame}

The non-governmental organisation (NGO) frame, which the United Nations (UN) created in 1945 in order to formalise how non-state actors participate in UN processes, has become increasingly prevalent in politics and academia, particularly in the 1980s and 1990s when neoliberal agendas sought to push back the state and allocate tasks to markets and other actors, including NGOs (Lewis 2010). However, "while the term "NGO" is widely used, there are also many other overlapping terms such as "non-profit", "voluntary", and "civil society organisations" (Lewis 2010, p. 1057), which may be related to historical path dependencies in term usage in different parts of the world,
Fig. 2 Frame usage of academic publications on nonstate actors in the EU

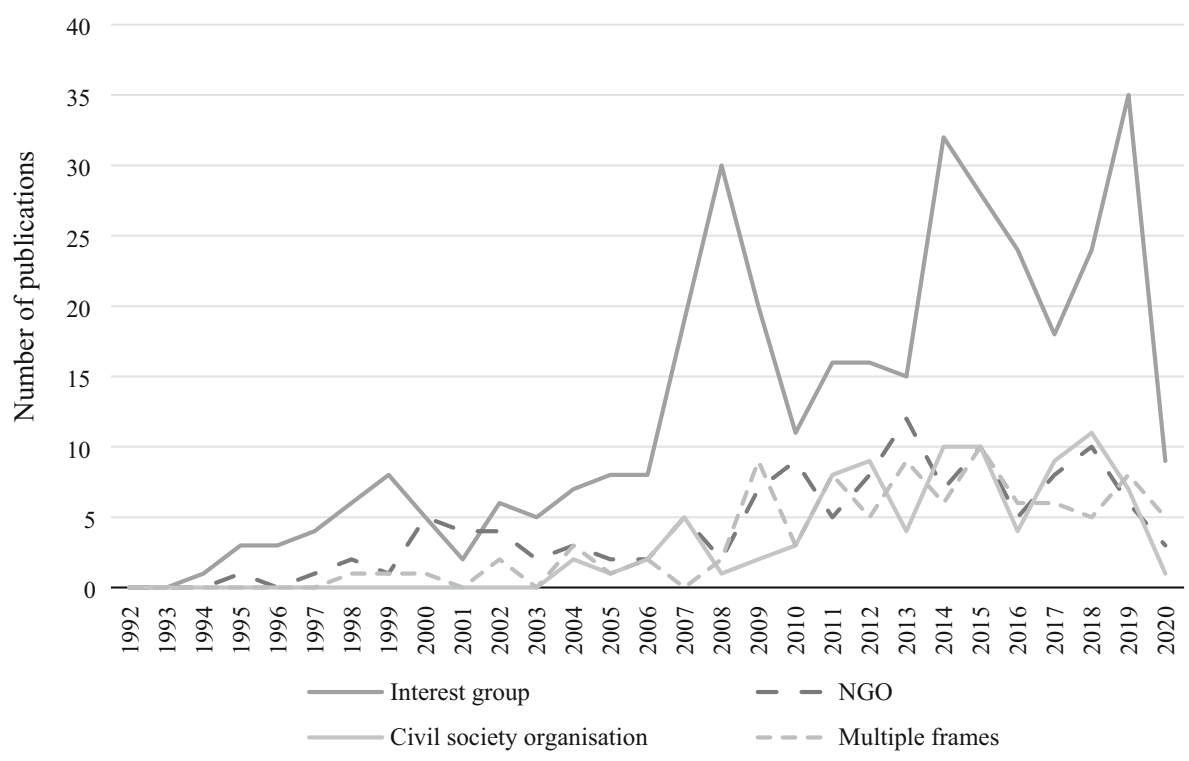




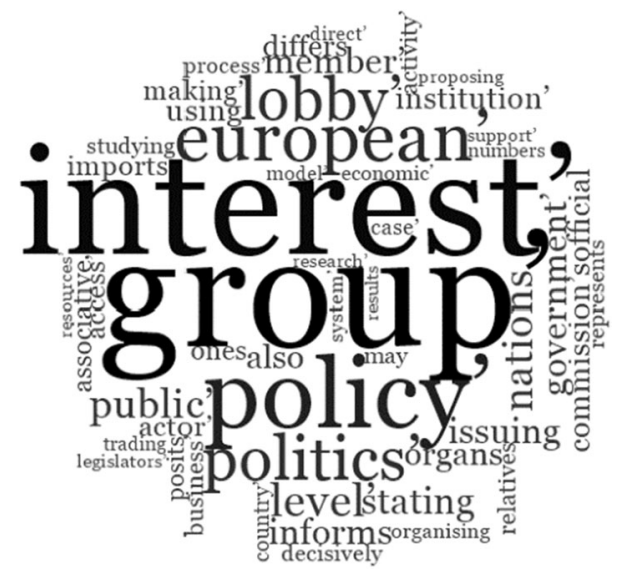

Fig. 3 Interest group frame

but also to the fact that NGOs tend to be very diverse organisations (Lewis 2010). Lewis (2010) argues that NGO activities may be understood in two broad categories: service provision and political advocacy. Many of the NGOs active in the EU are indeed 'umbrella organisations' performing political advocacy for a range of NGOs in their membership (Melville 2010), or they represent globally active organisations such as Greenpeace or the WWF.

On a fairly basic level, the term NGO signifies an organisation that is neither governmental nor part of the market (therefore sometimes also described as belonging to the 'third sector'). This framing becomes a source of legitimacy derived from a perceived sense of independence. Given that some environmental groups such as Greenpeace have great capacity to attract public attention, and tend to self-identify as NGOs, the expression has stuck in the public and academic mind. The concept NGO became popular in order to describe organisations that are perceived to be 'defenders of the public interest, presenting neutral, value-free accounts of issues and problems', driven by positive media images and public stunts (Grant 2001, p. 338). Although this frame has been criticised for a number of reasons, it enjoys considerable use and appreciation (see Giddens 2011). This is especially true in the environmental sector and with a view to a few other campaigning causes (Grant 2001). The keyword analysis of publications with the term 'NGO' in the title/abstract corroborates these arguments from the literature. The words 'environment' and 'social' are among the top ten words used in these publications, and 'stakeholders' in 54th place. 'Governs' appears in 15th place, while the word 'members' appears in (20th) place (see Fig. 4).

Many have argued that NGOs are the basic element or constitutive part of civil society (Kohler-Koch and Rittberger 2006). These claims notwithstanding, in contrast to the orientation towards democratic theory in the CSO frame (see below), the NGO frame contains notions of governance-as supported by the keywords above-an organisational form that envisions networks, rather than hierarchies of government, at the root of societal steering (Fukuyama 2016; Rhodes 2007). The underlying rationale here is different from approaches to civil society that rely on participatory or deliberative notions, mainly with a strong connection to state structures.

\section{The 'Civil Society [Organisation]' Frame}

While relatively well developed in political theory (e.g. Cohen and Arato 1992), civil society remains a contested concept in the social sciences (Paturyan 2011). According to Edwards (2011), this is in part because it first emerged as a broad concept of a 'sphere of uncoerced human association between the individual and the state [...] relatively independent of government and the market' (p. 3). Origins of ideas on civil society can be traced to scholars running from Aristotle to Jean-Jacques Rousseau, Georg W.F. Hegel, John Dewey, Antonio Gramsci, Jürgen Habermas and others (Anheier et al. 2010; Ehrenberg 2011). While their arguments cannot be reviewed in depth here, it is important to highlight that civil society has typically been understood to be a sphere that is complementary to politics and markets (Cohen and Arato 1992). Today, there are three broad ways to conceptualise society: as a sphere of voluntary action; as a 'kind of society' with a specific set of norms; and as 'a space for citizen action and engagement' in the public sphere (Edwards 2011, p. 7).

Correspondingly, researchers use civil society ideas in three broad ways (Keane 2010): as an 'idealtyp' in empirical investigations of its origins and nature; in pragmatic ways, where 'strategic usages of the term have an eye for defining what must or must not be done' (p. 463); or normatively, where civil society stands for an expression

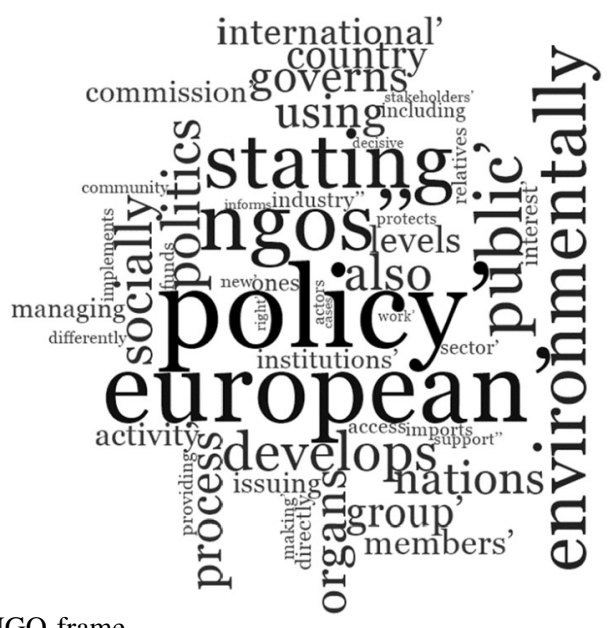

Fig. 4 NGO frame 
of 'good society', often filling gaps left by markets and states. In contrast to NGOs (see above), civil society is often conceptualised as working 'with the state' (Cohen and Arato 1992) and contains positive connotations, because it is thought to connect citizens with their governing institutions. Scholars consequently often link civil society with participatory and deliberative approaches to democracy, particularly in the EU context (e.g. KohlerKoch 2010c; Smismans 2003; see also Habermas 1996), a notion that appears to bear out in terms of representation and transmission in a more recent empirical analysis (Rodekamp 2013, p. 258-259).

The results from the keyword analysis of academic publications with 'civil society' in the abstract/title corroborate the latter point. The word 'members' appears in the top twenty words used in these publications, followed by 'participative' (21st place), 'represents' (22nd) and 'associative' (35th). In sum, the keywords also suggest that the concept of civil society in the EU context links with academic discussions about EU democracy and citizen engagement (see Fig. 5).

The origins of this linkage may be traced to the late 1990s, when civil society was framed as a democratising force in order to remedy the EU's democratic and legitimacy crisis after the fall of the Santer Commission (Smismans 2003). A small number of individuals, including academic Stijn Smismans and a handful of Commission officials around Jerome Vignon, were instrumental in framing civil society as a solution to the EU's crisis (Michel 2008; Smismans 2006). In what finally became the White Paper on European governance (European Commission 2001), they left notions of civil society, participation, and dialogue sufficiently vague in order to unite actors with different ideas on civil society and democracy to address the democratic deficit (Michel 2008). The civil society concept proved broad enough to address both

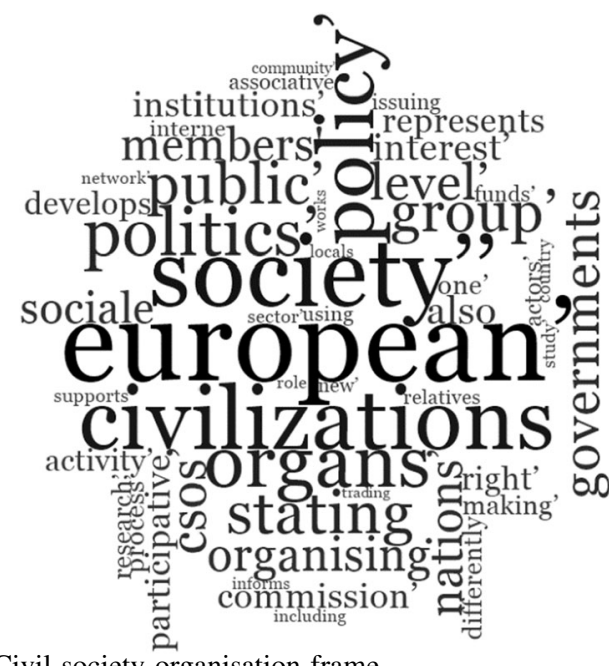

Fig. 5 Civil society organisation frame philosophical concerns about democratic legitimacy and the practical needs of consultation (Michel 2008; Freise 2008; Smismans 2006). It follows that the fuzziness of the frame enabled its efficacy at the European level (Michel 2008), but people continued to pursue their own visions of European governance within it.

This state of affairs continues to generate disagreement among academics '[...] not just because the concept of civil society is ambiguous but also because civil society is linked to different images of the nature of the European polity' (Kohler-Koch 2009, p. 47; see also Kohler-Koch 2010a). Finke (2007, p. 1) explains that '[...] two scholars who refer to "civil society" do not necessarily mean the same thing and this is even less obvious if journalists, politicians or public officials allude to civil society'. For example, Kohler-Koch and Quittkat (2009) found in a survey that whether or not scholars classify an organisation as civil society depends on their underlying democratic ideals. People who adhere to pluralist or governance visions classify trade unions or firms as civil society organisations as long as they add to the number of voices represented in EU political discourse (Kohler-Koch and Quittkat 2009). By contrast, scholars with deliberative or participatory perspectives may only classify general interest organisations as civil society (Kohler-Koch and Quittkat 2009).

Particularly for those emphasising participatory and deliberative notions, evidence showing that CSOs in the EU struggle to engage citizens in EU policy-making processes challenges this positive framing (Kohler-Koch 2010b; Kohler-Koch and Quittkat 2013; Warleigh 2001). The positive normative overtones of this frame may thus obscure empirical realities. As Apthorpe (1997, p. 43f) explains,

[...] we should also be suspicious of a term which is agreed among so many people, which everybody likes, and which everybody is in favour of. One crucial characteristic of these sorts of keywords is that they do not require an opposite word to give or enhance their meaning. They acquire much of their winning warmth from their popular meanings in everyday usage. A further characteristic is that, as a rule, they are not ever put to serious empirical testor if they are, and they fail, they continue to circulate in good currency nevertheless.

Indeed, discussions of CSOs' less favourable features are slow to emerge (e.g. Chambers and Kopstein 2001) and much empirical and theoretical work remains in order to understand how positively viewed normative notions of participatory and deliberative democracy embedded in the civil society frame play out in practice. 


\section{Multiple Frames}

This analysis reveals a smaller, but growing number of articles that include multiple frames (see Fig. 2). There are in principle two types of publications that use multiple frames: first, there are publications that use the frames carelessly and interchangeably without paying attention to their underlying normative dimensions. Such use is unfortunate, because it convolutes concepts and frames and thus potentially leads to confusion. By contrast, there are those who deliberately engage with and explore different frames and concepts with a view to understanding their differences (e.g. Enjolras et al. 2018, chapters 1 and 2; Salamon and Sokolowski 2016) - a welcome endeavour to which the current paper also seeks to contribute in a systematic fashion. The keyword analysis represents a melange of different approaches, including words such as 'interest', 'group', but also 'members' and 'participative'. See Fig. 6.

\section{Summary}

The three most popular frames on non-state actors in the EU emerging from the bibliographic analysis are 'interest group', 'NGO', 'civil society organisation', and the publications using multiple frames. Frame contents indicate that these connect with liberal democracy and pluralism (interest groups), governance (NGO), and deliberative/participatory democracy (CSO) ideals of the European polity. See Table 2.

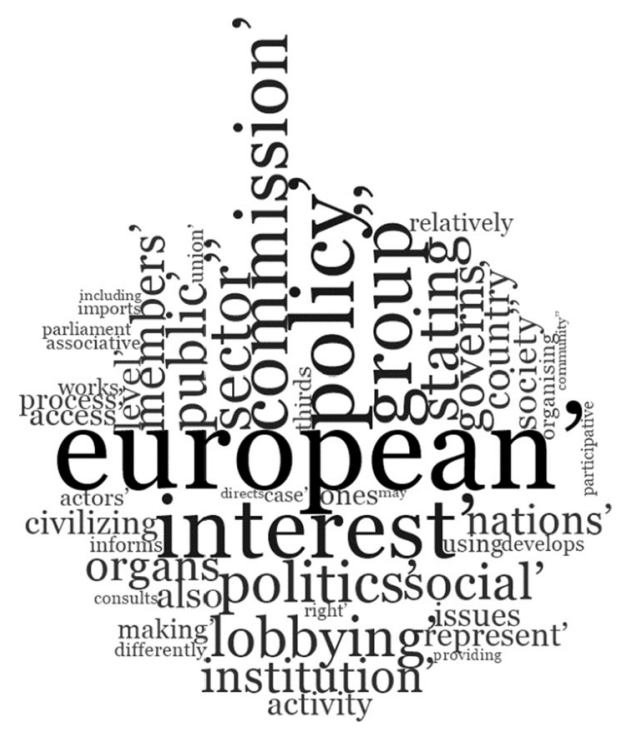

Fig. 6 Multiple frames

\section{Discussion and Conclusion}

This paper set out to identify and describe prevalent frames used to describe non-state actors in the EU in academic publications. Framing non-state actors is relevant for academic study and for ongoing debates about the European democratic deficit, which have often admonished a perceived distance between the EU and its citizens (Saurugger 2008). The bibliometric analysis of a novel literature database containing 780 publications that appeared between 1992 and 2020 presented in this paper suggests three main frames used to describe non-state actors in research in the EU, namely 'interest group', 'nongovernmental organisation (NGO)', and 'civil society organisation' (CSO). The use of these frames is not (and should not be) random or interchangeable. Rather, this paper demonstrates that each frame contains specific normative visions about the role of non-state actors in the EU's evolving democracy, which the previous sections have unpacked (see also Kutay 2017). For example, in relevant literatures, non-state actors-then usually re-framed as 'civil society organisations' - are thought to potentially plug the democratic deficit, though caveats apply (e.g. Saurugger 2008).

These findings chime with how EU policy-makers have used 'civil society' terminology (Freise 2008). For example, in the important White Paper on European Governance, ${ }^{7}$ the European Commission uses a very broad definition of civil society to claim that

Civil society plays an important role in giving voice to the concerns of citizens and delivering services that meet people's needs. [...] Nongovernmental organisations play an important role at global level in development policy. (European Commission 2001, p. 14)

What is striking in this document is that the term 'lobbying' is not used at all, the term 'interest groups' is cited once (p. 34), but 'civil society' seventeen times; 'nongovernmental organisations' is only used once (see quote above). More generally, Kohler-Koch and Finke (2007) show that the European Commission has moved from talking about 'special interest groups' to 'NGOs' and finally 'CSOs' across a range of policy documents. This has resulted from a shift in the Commission from consulting interests towards notions of participatory democracy (Kohler-Koch and Finke 2007)_-though this paper suggests that across academic literatures, this focus may be waning. European policy-makers evidently use frames about non-state actors strategically in order to make claims about their role in the European polity (Smismans 2003).

\footnotetext{
$\overline{7}$ The White Paper was not included in the literature database, because it is not an academic publication.
} 
Table 2 Key frames in publications on non-state actors in the EU

\begin{tabular}{ll}
\hline Concept/terminology & Key contents of the underlying frame \\
\hline Interest group & $\begin{array}{c}\text { 'Influence'. Focus on organisation, aggregation of interests, and political advocacy; perceived neutrality in academic } \\
\text { circles; often in pluralist/liberal democratic frameworks ('Europe of interests'). Keyword 'members' less significant. } \\
\text { 'Environmental'; 'social'. An organisation separate from the state/government and the market; often positive } \\
\text { connotation; often used for environmental organisations; often used in conceptual frameworks of 'governance'. }\end{array}$ \\
$\begin{array}{c}\text { Civil society } \\
\text { organisation }\end{array}$ & $\begin{array}{l}\text { Democracy'; 'participation'; 'accountability'; 'legitimacy'; 'member'; 'citizen'. Focus on citizens and the connection } \\
\text { democratic frameworks; generally positive connotation in public/academic debates. }\end{array}$ \\
\hline
\end{tabular}

Source: Own keyword analysis and literature review

The findings from this paper may help practitioners to use the concepts in a way that furthers their aims, while remaining cognizant of the alternatives. It is therefore important to pay attention to the frames that EU policymakers evoke, because 'policy language [...] is itself a form and source of policy power' (Apthorpe 1997, p. 42). This analysis shows that in corresponding academic work, the interest group frame has gained force at the expense of civil society organisations and the other frames over the last two decades.

Dynamic framing of non-state actors in the EU furthermore has the potential to reveal developments in EU governance, which has been described as a polity-in-themaking. As new states join the EU (e.g. Croatia in 2013) and others leave (UK in 2020) and the policy-making activities of the EU change, the role of non-state actors is constantly being evaluated and contested. This is particularly relevant in light of continuous efforts to adjust nonstate actor regulation in the EU (Greenwood and Dreger 2013). In addition, potential roles of non-state actors matter for addressing the EU's perceived democratic deficit. Kohler-Koch and Rittberger (2007, p. 11) write:

The political discourse supporting institutional reforms in the EU is quite evidently inspired by the mainstream debate in academia that the present institutions of liberal democracy are not operating satisfactorily, that a key problem is the lack of civic engagement and, therefore, a main concern how to promote effective citizenship.

Given that academics can become involved in EU policy-making in multiple ways (e.g. Gornitzka and Sverdrup 2008), developing a clearer understanding of their framing of non-state actors may open up possibilities to understand how academic and policy-maker frames interact and how academia influences the development of the European polity. But this also means that academic framing may influence the success of responses to issues such as the
European democratic deficit (see Peters and Hoornbeek 2005).

Academic framing may be a slower process than in the world of public policy-making, and it tends to be less action-oriented than in social movements/among policymakers. However, similar general principles apply-academic leaders frame or re-frame phenomena, frames interact with political and social realities and serve to attract followers, who could be other academics, students, or policy-makers. Future research should shed more light on the role of academics in political framing processes. If the EU institutions are receptive to academic voices, then their lobbying regulation and funding schemes for nonstate actors may change in response to the way in which these groups are understood. Research on non-state actors as such-and the dominant frames developed and used within that field-may have a collective impact that works over time to shape important aspects of the European polity.

One may argue that academic conceptual development on non-state actors should be separated from political framing processes. It is questionable whether such a separation is possible in principle or practice. Attempting to do so certainly risks creating an increasing distance between political realities and corresponding academic study, thereby overlooking academia's role in political framing processes and vice versa. In practical terms, the ongoing, networked cross-fertilisation between academia and EU politics makes strict separation all but impossible. A better approach is to study how dynamic framing processes unfold in different arenas, how they overlap and interact, and what political and conceptual consequences emerge from related developments. Of course, not all scholars who use a certain set of terminology may consciously argue for a particular democratic vision for Europe, or necessarily make a conscious choice to this effect. There may still be a significant degree of randomness in academic use.

Finally, if we accept Callon's (1998)'s rationale that frames are intrinsically dynamic, attempts to provide 'clear 
definitions' of terms (e.g. Jordan et al. 2004) may fail as the result of a continual process of re-framing and frame interaction. The current contribution may be understood as an analysis of a particular time, spanning nearly three decades. However, important insights could emerge from future studies seeking to shed light on why certain frames emerge in particular times, how academic and political frames interact, and how this relates to EU polity building.

Acknowledgements An earlier version of this paper was written as the second chapter of a Master of Philosophy (MPhil) thesis submitted to the Department of Geography and the Environment at the University of Oxford in 2013. The author thanks his thesis supervisor, Dr Paul Jepson, for support and advice during this period. In updating and re-working the paper prior to publication, the Technical University of Darmstadt and especially Prof. Kai Schulze's research group provided for an excellent research environment. Finally, the author is grateful to the anonymous peer reviewers, whose constructive comments considerably strengthened the paper.

Funding Open Access funding enabled and organized by Projekt DEAL. Funding was provided by St. Cross College, University of Oxford (Student Travel and Research Grant), and the Technical University of Darmstadt (Ingenium Support Package Grant).

\section{Compliance with Ethical Standard}

Conflict of interest On behalf of all authors, the corresponding author states that there is no conflict of interest.

Open Access This article is licensed under a Creative Commons Attribution 4.0 International License, which permits use, sharing, adaptation, distribution and reproduction in any medium or format, as long as you give appropriate credit to the original author(s) and the source, provide a link to the Creative Commons licence, and indicate if changes were made. The images or other third party material in this article are included in the article's Creative Commons licence, unless indicated otherwise in a credit line to the material. If material is not included in the article's Creative Commons licence and your intended use is not permitted by statutory regulation or exceeds the permitted use, you will need to obtain permission directly from the copyright holder. To view a copy of this licence, visit http://creativecommons. org/licenses/by/4.0/.

\section{References}

Albareda, A., \& Braun, C. (2019). Organizing transmission belts: The effect of organizational design on interest group access to EU Policy-making. Journal of Common Market Studies, 57(3), 468-485.

Andrés, A. (2009). Measuring academic research: How to undertake a bibliometric study. Oxford: Chandos Publishing.

Anheier, H. K., Toepler, S., \& List, R. (Eds.). (2010). International encyclopedia of civil society. New York: Springer.

Apthorpe, R. (1997). Writing development policy and policy analysis plain or clear: On language, genre and power. In C. Shore \& S. Wright (Eds.), Anthropology of policy: Critical perspectives on governance and power (pp. 43-58). London; New York: Routledge.

Arras, S., \& Beyers, J. (2020). Access to European Union agencies: Usual suspects or balanced interest representation in open and closed consultations? Journal of Common Market Studies, 58(4), 836-855.

Baroni, L., Carroll, B. J., Chalmers, A. W., Marquez, L. M. M., \& Rasmussen, A. (2014). Defining and classifying interest groups. Interest Groups \& Advocacy, 3(2), 141-159.

Benford, R. D., \& Snow, D. A. (2000). Framing processes and social movements: An overview and assessment. Annual Review of Sociology, 26(1), 611-639.

Berkhout, J., Carroll, B. J., Braun, C., Chalmers, A. W., Destrooper, T., Lowery, D., et al. (2015). Interest organizations across economic sectors: Explaining interest group density in the European Union. Journal of European Public Policy, 22(4), 462-480.

Beyers, J., Eising, R., \& Maloney, W. (2008). Researching interest group politics in Europe and elsewhere: Much we study, little we know? West European Politics, 31(6), 1103-1128.

Boräng, F., \& Naurin, D. (2015). 'Try to see it my way!' Frame congruence between lobbyists and European Commission officials. Journal of European Public Policy, 22(4), 499-515.

Boräng, F., Eising, R., Klüver, H., Mahoney, C., Naurin, D., Rasch, D., et al. (2014). Identifying frames: A comparison of research methods. Interest Groups \& Advocacy, 3(2), 188-201.

Bouwen, P. (2009). The European Commission. In D. Coen \& J. Richardson (Eds.), Lobbying the European Union: Institutions, actors, and issues (pp. 19-38). Oxford: Oxford University Press.

Bunea, A., \& Baumgartner, F. R. (2014). The state of the discipline: Authorship, research designs, and citation patterns in studies of EU interest groups and lobbying. Journal of European Public Policy, 21(10), 1412-1434.

Callon, M. (1998). An essay on framing and overflowing: Economic externalities revisited by sociology. In M. Callon (Ed.), The laws of the markets (pp. 244-269). Oxford; Malden, MA: Blackwell Publishers.

Chambers, S., \& Kopstein, J. (2001). Bad civil society. Political Theory, 29(6), 837-865.

Chong, D., \& Druckman, J. N. (2007). Framing theory. Annual Reviews of Political Science, 10, 103-126.

Clapham, A. (2009). Non-state actors (in postconflict peace-building). In V. Chetail (Ed.), Postconflict peace-building: A lexicon (pp. 200-212). Oxford: Oxford University Press.

Coen, D., \& Katsaitis, A. (2019). Between cheap talk and epistocracy: The logic of interest group access in the European Parliament's committee hearings. Public Administration, 97(4), 754-769.

Cohen, J. L., \& Arato, A. (1992). Civil society and political theory. Cambridge, Massachusetts: MIT Press.

Commission, European. (2001). European governance: A white paper. Brussels: European Commission.

Creed, W. D., Langstraat, J. A., \& Scully, M. A. (2002). A picture of the frame: Frame analysis as technique and as politics. Organizational Research Methods, 5(1), 34-55.

Dalziel, R. (2010). Interest and pressure groups. In H. K. Anheier, S. Toepler, \& R. List (Eds.), International encyclopedia of civil society (pp. 867-870). New York: Springer.

Doliwa-Klepacka, A. (2011). Ways of influencing the process of law establishment by lobby groups in the European Union. Studies in Logic, Grammar and Rhetoric, 26(39), 245-255.

Donohue, J. C. (1973). Understanding scientific literatures: A bibliometric approach. Cambridge, Mass; London: MIT Press.

Dür, A. (2007). The question of interest group influence. Journal of Public Policy, 27(1), 1-12.

Edwards, M. (2011). Introduction: Civil society and the geometry of human relations. In M. Edwards (Ed.), (pp. 3-14). Oxford: Oxford University Press.

Ehrenberg, J. (2011). The history of civil society ideas. In M. Edwards (Ed.), The Oxford handbook of civil society (pp. 15-28). Oxford: Oxford University Press. 
Eising, R., \& Lehringer, S. (2013). Interest groups and the European Union. In M. Cini \& N. Pérez-Solórzano Borragán (Eds.), European Union politics (4th ed., pp. 183-195). Oxford: Oxford University Press.

Enjolras, B., Salamon, L. M., Henrik Sivesind, K., \& Zimmer, A. (2018). The third sector as a renewable resource for Europe: Concepts, impacts, challenges and opportunities. Cham, Switzerland: Springer.

Entman, R. M. (2009). Projections of power: Framing news, public opinion, and US foreign policy. Chicago: University of Chicago Press.

Finke, B. (2007). Civil society participation in EU governance. Living Reviews in European Governance, 2. Retrieved October 20, 2020 from http://www.europeangovernancelivingreviews.org/ Articles/lreg-2012-2/.

Freise, M. (2008). The civil society discourse in Brussels-between societal grievances and utopian ideas. In M. Freise (Ed.), European civil society on the road to success? (pp. 21-45). Baden Baden: Nomos.

Fukuyama, F. (2016). Governance: What do we know, and how do we know it? Annual Review of Political Science, 19, 89-105. https:// doi.org/10.1146/annurev-polisci-042214-044240.

Gamson, W. A., \& Entman, Robert M. (2005). Projections of power: framing news, public opinion, and US foreign policy. Public Opinion Quarterly, 69(2), 324-326.

Giddens, A. (2011). The politics of climate change. Cambridge; Malden, MA: Polity.

Goffman, E. (1974). Frame analysis: An essay on the organization of experience. New York: Harper \& Row.

Gornitzka, A., \& Sverdrup, U. (2008). Who consults? The configuration of expert groups in the European Union. West European Politics, 31(4), 725-750.

Grant, W. (2001). Pressure politics: From 'insider' politics to direct action? Parliamentary Affairs, 54(2), 337-348.

Greenwood, J. (2017). Interest representation in the European Union (4th ed.). New York: Palgrave Macmillan.

Greenwood, J., \& Dreger, J. (2013). The transparency register: A European vanguard of strong lobby regulation? Interest Groups \& Advocacy, 2(2), 139-162.

Habermas, J. (1996). Between facts and norms: Contributions to a discourse theory of law and democracy (William Rehg Trans.). Cambridge, Massachusetts: MIT Press.

Held, D. (2006). Models of democracy (3rd ed.). Cambridge: Polity Press.

Jordan, G., Halpin, D., \& Maloney, W. (2004). Defining interests: Disambiguation and the need for new distinctions? The British Journal of Politics \& International Relations, 6(2), 195-212.

Keane, J. (2010). Civil society, definitions and approaches. In H. K. Anheier, S. Toepler, \& R. List (Eds.), International encyclopedia of civil society (pp. 461-464). New York: Springer.

Klüver, H. (2013). Lobbying in the European Union: Interest groups, lobbying coalitions, and policy change. Oxford: Oxford University Press.

Klüver, H., \& Mahoney, C. (2015). Measuring interest group framing strategies in public policy debates. Journal of Public Policy, $35(2), 223-244$

Klüver, H., \& Saurugger, S. (2013). Opening the black box: The professionalization of interest groups in the European Union. Interest Groups \& Advocacy, 2(2), 185-205.

Kohler-Koch, B. (2009). The three worlds of European civil societywhat role for civil society for what kind of Europe? Policy and Society, 28(1), 47-57.

Kohler-Koch, B. (2010a). Civil society and the European Union. In H. K. Anheier, S. Toepler, \& R. List (Eds.), International encyclopedia of civil society (pp. 332-338). New York: Springer.
Kohler-Koch, B. (2010b). If participation does not do the job, will accountability make a difference? The role of CSO in EU accountability. Retrieved October 20, 2020 from http://www. mzes.uni-mannheim.de/publications/papers/Kohler_representa tion_accountability2010-1.pdf .

Kohler-Koch, B. (2010c). Civil society and EU democracy: 'Astroturf' representation? Journal of European Public Policy, 17(1), $100-116$.

Kohler-Koch, B., \& Finke, B. (2007). The institutional shaping of EU-society relations: A contribution to democracy via participation? Journal of Civil Society, 3(3), 205-221.

Kohler-Koch, B., \& Quittkat, C. (2009). What is civil society and who represents civil society in the EU?-Results of an online survey among civil society experts. Policy and Society, 28(1), 11-22.

Kohler-Koch, B., \& Quittkat, C. (2013). De-mystification of participatory democracy: EU-governance and civil society. Oxford: Oxford University Press.

Kohler-Koch, B., \& Rittberger, B. (2006). Review article: The 'governance turn' in EU studies. Journal of Common Market Studies, 44, 27-49.

Kohler-Koch, B., \& Rittberger, B. (2007). Charting crowded territory: Debating the democratic legitimacy of the European Union. In B. Kohler-Koch \& B. Rittberger (Eds.), Debating the democratic legitimacy of the European Union (pp. 1-29). Lanham, MD: Rowman \& Littlefield.

Kutay, A. (2017). How does the European Commission create a European civil society with words? A discourse theoretical inquiry. Journal of Common Market Studies, 55(5), 1094-1109.

Lakoff, G. (2004). Don't think of an elephant: Know your values and frame the debate: The essential guide for progressives. White River Junction: Chelsea Green Publishing.

Lewis, D. (2010). Nongovernmental organizations, definition and history. In H. K. Anheier, S. Toepler, \& R. List (Eds.), International encyclopedia of civil society (pp. 1056-1062). New York: Springer.

Maloney, W. A., Hafner-Fink, M., \& Fink-Hafner, D. (2018). The impact of the EU accession process and EU funding on the professionalization of national interest groups: The Slovenian case. Interest Groups \& Advocacy, 7(1), 41-60.

Mansbridge, J. J. (1992). A deliberative theory of interest representation. In M. P. Petracca (Ed.), The politics of interests: Interest groups transformed (pp. 32-57). Boulder: Westview Press.

Mazey, S., \& Richardson, J. (1997). The Commission and the lobby. In G. Edwards \& D. Spence (Eds.), The European Commission (2nd ed., pp. 178-212). London: Cartermill.

Melville, R. (2010). Umbrella organizations. In H. K. Anheier, S. Toepler, \& R. List (Eds.), International encyclopedia of civil society (pp. 1577-1582). New York: Springer.

Michel, H. (2008). Incantations and uses of civil society by the European Commission. In B. Jobert \& B. Kohler-Koch (Eds.), Changing images of civil society: From protest to governance (pp. 107-119). New York: Taylor \& Francis.

Paturyan, Y. (2011). Civil society and democracy: Disentangling mutual influences. Saarbrücken: VDM Verlag.

Peters, B. G., \& Hoornbeek, J. (2005). The problem of policy problems. In F. P. Eliadis, M. M. Hill, \& M. Howlett (Eds.), Designing government: From instruments to governance (pp. 77-105). Montreal: Queen's University Press.

Rein, M., \& Schön, D. (1991). Frame-reflective policy discourse. In P. Wagner, C. Hirschon Weiss, B. Wittrock, \& H. Wollmann (Eds.), Social sciences and modern states: National experiences and theoretical crossroads (pp. 262-289). Cambridge; New York: Cambridge University Press.

Rhodes, R. A. W. (2007). Understanding governance: Ten years on. Organization Studies, 28(8), 1243-1264. 
Rodekamp, M. (2013). Their members' voice: Civil society organisations in the European Union. Wiesbaden: VS Verlag für Sozialwissenschaften.

Ruzza, C. (2004). Europe and civil society: Movement coalitions and European governance. Manchester: Manchester University Press.

Salamon, L. M., \& Sokolowski, S. W. (2016). Beyond nonprofits: Reconceptualizing the third sector. International Journal of Voluntary and Nonprofit Organizations, 27(4), 1515-1545.

Sartori, G. (1970). Concept misformation in comparative politics. The American Political Science Review, 64(4), 1033-1053.

Saurugger, S. (2008). Interest groups and democracy in the European Union. West European Politics, 31(6), 1274-1291.

Shore, C., \& Wright, S. (1997). Anthropology of policy: Critical perspectives on governance and power. London; New York: Routledge.

Smismans, S. (2003). European civil society: Shaped by discourses and institutional interests. European Law Journal, 9(4), 473-495.

Smismans, S. (2006). Civil society and legitimate European governance. Cheltenham, UK; Northampton, MA: Edward Elgar.
Snow, D. A., Rochford, E. B., Worden, S. K., \& Benford, R. D. (1986). Frame alignment processes, micromobilization, and movement participation. American Sociological Review, 51(4), 464-481.

Tarrow, S. (1992). Mentalities, political cultures, and collective action frames. In A. D. Morris \& C. M. Mueller (Eds.), Frontiers in social movement theory (pp. 174-202). New Haven: Yale University Press.

Truman, D. B. (1951). The governmental process: Political interests and public opinion. New York: Knopf.

Warleigh, A. (2001). 'Europeanizing' civil society: NGOs as agents of political socialization. Journal of Common Market Studies, 39(4), 619-639.

Warleigh, A. (2003). Democracy in the European Union: Theory, practice and reform. London: Sage.

Wonka, A., Baumgartner, F. R., Mahoney, C., \& Berkhout, J. (2010). Measuring the size and scope of the EU interest group population. European Union Politics, 11(3), 463-476.

Publisher's Note Springer Nature remains neutral with regard to jurisdictional claims in published maps and institutional affiliations. 